\title{
Optimized Protocol for Cyanobacterial 16S rRNA Analysis in Danube Delta Lakes
}

\author{
Maria Iasmina Moza 1,2,3,*iD, Carmen Postolache $1,4, *$ (D)
}

1 Faculty of Biology, University of Bucharest, Department of Systems Ecology and Sustainable Development, Doctoral School in Ecology, 91-95 Splaiul Independenței St., district 5, 050095, Bucharest, Romania, iasmina_moza@yahoo.com (M.I.M.);

2 Foundation Conservation Carpathia, Wildlife Genetic Monitoring Laboratory, Calea Feldioarei nr. 27, 500450, Brasov, Romania

3 Swiss Federal Institute for Environmental Science and Technology-Eawag, Überlandstrasse 133, P.O.Box 611, 8600, Dübendorf, Switzerland

4 Research Institute of the University of Bucharest - ICUB, 36-46 Bd. M. Kogalniceanu St., district 5, 050107, Bucharest, Romania, carmen_postolache83@yahoo.com (C.P.);

* Correspondence: iasmina_moza@yahoo.com (M.I.M.), carmen_postolache83@yahoo.com (C.P.);

Scopus Author ID 55322234000

Received: 10.04.2021; Revised: 15.05.2021; Accepted: 18.05.2021; Published: 20.05.2021

\begin{abstract}
Molecular biology protocols have been more and more accessible to researchers for ecological investigations. However, these protocols always require optimization steps for the analysis of specific types of samples. This study aimed to optimize a molecular protocol to analyze cyanobacterial 16S rRNA in Danube Delta shallows lakes. In this regard, several commercial DNA extraction kits were tested compared to the potassium ethyl xanthogenate extraction method on different matrices. The obtained DNA was further used for 16S rRNA PCR optimization. Finally, an optimized protocol is proposed for the molecular analysis of the cyanobacteria group in freshwater samples. The best DNA extraction method was the potassium xanthogenate extraction from dried cyanobacterial biomass. A dynamic in total genomic eDNA was observed, reflecting the seasonal difference in phytoplankton biomass from the studied lakes. The PCR protocol optimized by us can be successfully applied for the identification of a broad range of cyanobacterial genetic markers.
\end{abstract}

Keywords: toxic cyanobacteria; Danube Delta; eDNA extraction; PCR optimization; shallow lakes.

(C) 2021 by the authors. This article is an open-access article distributed under the terms and conditions of the Creative Commons Attribution (CC BY) license (https://creativecommons.org/licenses/by/4.0/).

\section{Introduction}

Cyanobacteria are an ancient group of autotrophic bacteria living both in freshwater and marine environments and constituting an important component of the primary producers $[1,2]$. Mass populations of toxic cyanobacteria represent a global phenomenon, and the recent recognition that incidences of blooms may increase significantly under climate change serves to reinforce further the seriousness of the potential risks to human health [3]. In recent years, the increased temperatures triggered a higher frequency of cyanobacteria blooming, including species with the potential to release toxins in the Danube Delta Biosphere Reserve [4], thus accentuating the health risk hazards. There is a high diversity of aquatic ecosystems here, and consequently, high diversity and variability of the phytoplankton community, which makes it difficult to predict the occurrence of toxic cyanobacteria bloom only by using the classic methods (e.g., microscopy or fluorometry). For this reason, molecular analyses focusing on the 
identification of genes able to release toxins during the blooms may complement the classic methods and contribute to predicting a certain "toxic bloom" pattern to reduce casualties.

Since most microorganisms are uncultivable in the laboratory, DNA isolation and PCR provide a powerful tool for studying microorganisms directly from environmental samples [5]. These techniques are currently used in microbial ecology [6] to identify a broad range of cyanobacterial genetic markers and quantify structural and functional properties of cyanobacterial communities in both field and laboratory conditions [7, 8]. However, the protocol for DNA extraction requires optimization in the case of environmental samples, for particular matrices, and for certain taxonomic groups, respectively [9-17].

For cyanobacteria DNA extraction, adapted protocols are needed even for each group apart [18] since their cell walls contain large amounts of cellulose, pectins, murein, and xylose [19] which interfere with the cell lysis and DNA isolation leading to only small amounts of DNA, also contaminated. Moreover, cyanobacteria form a mucous envelope, which protects the cells against various environmental factors [19]. Particularly, benthic forms can produce protective sheaths or mucilage [20] that harden the analysis since they interfere with DNA extraction. For the Danube Delta we reported plenty of filamentous but also colony-forming species [21]. Most of them have enormous quantities of mucopolysaccharides that make DNA extraction very challenging [22]. The quality and quantity of extracted DNA can be then tested using two methods: spectrophotometer quantification, PCR, and electrophoresis on agarose gel [13].

This study represents the first attempt focusing on culture-independent studies of cyanobacteria from Danube Delta shallow lakes. Therefore, we aimed to: (1) find the best methods for extraction of high-quality DNA using different preservation protocols and several commercial kits, and the lab-made potassium ethyl xanthogenate extraction buffer (XS buffer) and (2) to optimize a PCR protocol for $16 \mathrm{~S}$ ribosomal RNA gene amplification.

\section{Materials and Methods}

\subsection{Study sites.}

The Danube Delta is a Biosphere Reserve (DDBR) located at $45^{\circ} 0$ ' $\mathrm{N}$ latitude and $29^{\circ} 0^{\prime} \mathrm{E}$ longitude in the eastern part of Romania and comprises more than 400 lakes, well interconnected by a complex network of natural and man-made channels as well as by river branches [23, 24]. We sampled a number of lakes (Figure 1 and Table 1) belonging to all four lake complexes (LCs) of DDBR, namely: Șontea-Furtuna (LC 1), Isac-Gorgova (LC 2), MatițaMerhei (LC 3), forming the fluvial delta, and Roșu-Puiu (LC 4) part of the maritime delta [25]. The heterogeneity of the LCs also can be highlighted by the water level, which can be a surrogate for the hydrological regime [26], and it was shown to influence not only the water volume sampled but as well the ecological state of the lakes [21]. Water level can be considered, at the same time, a driver of the cyanobacteria community distribution in shallow lakes [21]. The water level in the DDBR lakes usually increases from West to East, following the water flow direction of the Sulina main branch. Figure 2 shows that the maximum water level in Danube Delta lakes during the dry period, when no pressures acted on the water regime (e.g., flooding) was registered in LC 4 (Roşu-Puiu), the most eastern complex forming the maritime delta. A detailed limnological description of the lakes was already done in previous papers $[27,28]$. The sampling campaigns were carried out preliminary in October 2012 (12 
lakes) and in spring (May), summer (July), and autumn (September) in 2013 (26 lakes) in order to include the seasonal dynamics of the cyanobacteria communities.

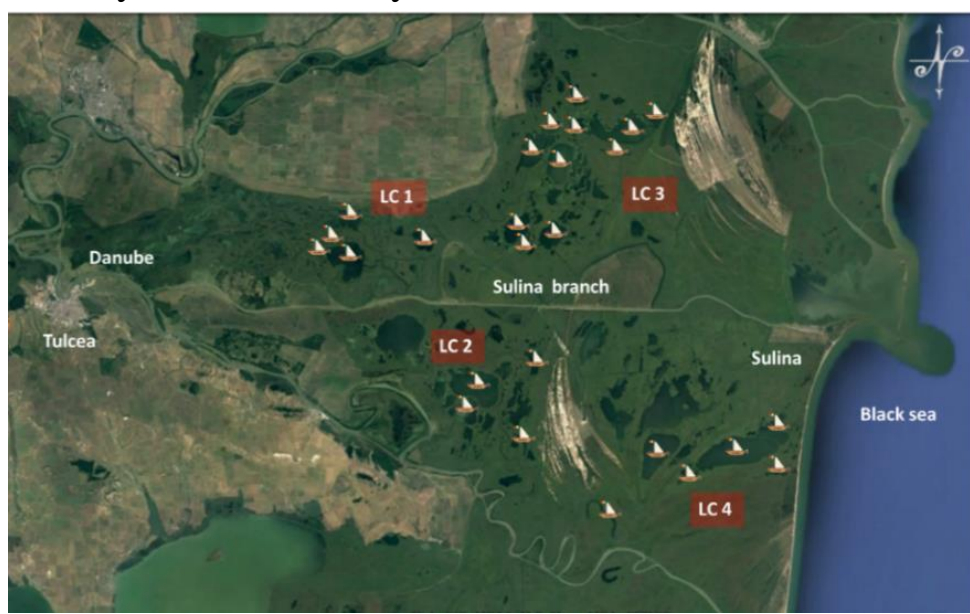

Figure 1. Danube Delta map (obtained with Google Earth Pro in 29.04.2020) with lakes (indicated with boats) and lake complexes (LC): Șontea-Furtuna (LC 1), Isac-Gorgova (LC 2), Matița-Merhei (LC 3), and Roșu-Puiu (LC 4) sampled during our survey in 2013.

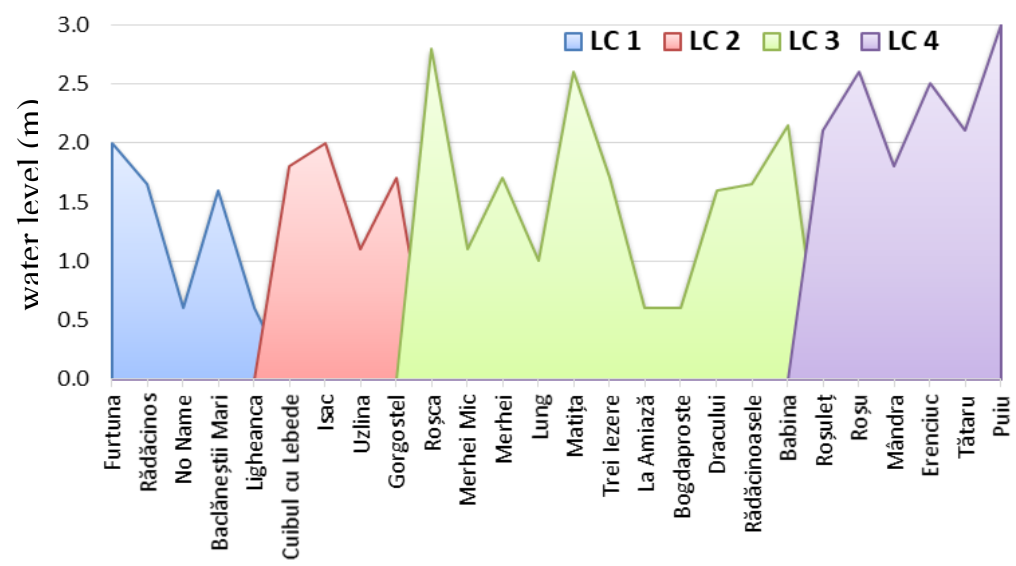

Figure 2. Water level during July 2013 for every studied lake comprised in lake complexes displayed from West to East: Șontea-Furtuna (LC 1), Gorgova - Uzlina (LC 2), Matița-Merhei (LC 3), part of the fluvial delta and Roşu-Puiu (LC 4) part of the maritime delta.

Table 1. Lakes sampled from Danube Delta Biosphere Reserve in 2013 with their GPS coordinates of the sampling points (center of each lake) and the filtered water volume used for eDNA; lakes are listed from West

to East along Sulina main branch.

\begin{tabular}{|c|c|c|c|c|c|c|}
\hline \multirow{2}{*}{$\begin{array}{c}\text { Lake } \\
\text { complexes } \\
(\mathrm{W} \rightarrow \mathbf{E})\end{array}$} & \multirow{2}{*}{ Lake name } & \multirow{2}{*}{$\begin{array}{l}\text { Latitude N } \\
\quad \text { (DDM) }\end{array}$} & \multirow{2}{*}{$\begin{array}{c}\text { Longitude E } \\
\text { (DDM) }\end{array}$} & \multicolumn{3}{|c|}{ Filtered volume (L) } \\
\hline & & & & May & July & September \\
\hline \multirow{5}{*}{$\begin{array}{l}\text { Sontea-Furtuna } \\
\text { (LC 1) }\end{array}$} & Furtuna & $45^{\circ} 12.374^{\prime}$ & $29^{\circ} 12.189^{\prime}$ & 2.5 & 1 & 1.5 \\
\hline & Rădăcinos & $45^{\circ} 13.544^{\prime}$ & $29^{\circ} 05.545^{\prime}$ & 2 & 1 & 1.5 \\
\hline & No Name (new lake) & $45^{\circ} 13.955^{\prime}$ & $29^{\circ} 03.844^{\prime}$ & 0 & 1 & 0 \\
\hline & Băclăneștii Mari & $45^{\circ} 14.397^{\prime}$ & $29^{\circ} 07.996^{\prime}$ & 2 & 1.3 & 1.5 \\
\hline & Ligheanca & $45^{\circ} 12.376^{\prime}$ & $29^{\circ} 12.190^{\prime}$ & 2.5 & 1 & 1.5 \\
\hline \multirow{7}{*}{$\begin{array}{l}\text { Isac-Gorgova } \\
\text { (LC 2) }\end{array}$} & Isac & $45^{\circ} 06.728^{\prime}$ & $29^{\circ} 17.056^{\prime}$ & 1 & 1.3 & 1.5 \\
\hline & Uzlina & $45^{\circ} 05.524^{\prime}$ & $29^{\circ} 16.070^{\prime}$ & 1.3 & 1.5 & 1.3 \\
\hline & Cuibul cu Lebede & $45^{\circ} 08.426^{\prime}$ & $29^{\circ} 20.589^{\prime}$ & 2 & 1 & 1.5 \\
\hline & Gorgostel & $45^{\circ} 03.253^{\prime}$ & $29^{\circ} 19.692^{\prime}$ & 2 & 1.5 & 2 \\
\hline & Trei Iezere & $45^{\circ} 14.769^{\prime}$ & $29^{\circ} 19.212^{\prime}$ & 2.5 & 1.3 & 1.5 \\
\hline & La Amiază & $45^{\circ} 13.887^{\prime}$ & $29^{\circ} 19.826^{\prime}$ & 2.5 & 1.3 & 1.5 \\
\hline & Bogdaproste & $45^{\circ} 13.986^{\prime}$ & $29^{\circ} 20.935^{\prime}$ & 2 & 1.3 & 1.3 \\
\hline \multirow{5}{*}{$\begin{array}{l}\text { Matita-Merhei } \\
\text { (LC 3) }\end{array}$} & Matița & $45^{\circ} 17.862^{\prime}$ & $29^{\circ} 22.131^{\prime}$ & 2 & 0.5 & 1.3 \\
\hline & Merhei & $45^{\circ} 19.020^{\prime}$ & $29^{\circ} 25.693^{\prime}$ & 2 & 1 & 2 \\
\hline & Merhei Mic & $45^{\circ} 19.817^{\prime}$ & $29^{\circ} 28.596^{\prime}$ & 2 & 1.5 & 2 \\
\hline & Lung & $45^{\circ} 18.220^{\prime}$ & $29^{\circ} 26.102^{\prime}$ & 2 & 1.3 & 2 \\
\hline & Dracului & $45^{\circ} 19.508^{\prime}$ & $29^{\circ} 21.734^{\prime}$ & 2 & 1.5 & 1.3 \\
\hline
\end{tabular}




\begin{tabular}{|c|c|c|c|c|c|c|}
\hline \multirow{5}{*}{$\begin{array}{c}\text { Lake } \\
\text { complexes } \\
(\mathbf{W} \rightarrow \mathbf{E})\end{array}$} & \multirow{2}{*}{ Lake name } & \multirow{2}{*}{$\begin{array}{c}\text { Latitude } \mathbf{N} \\
\text { (DDM) }\end{array}$} & \multirow{2}{*}{$\begin{array}{c}\text { Longitude E } \\
\text { (DDM) }\end{array}$} & \multicolumn{3}{|c|}{ Filtered volume (L) } \\
\hline & & & & May & July & September \\
\hline & Rădăcinoasele & $45^{\circ} 18.945^{\prime}$ & $29^{\circ} 21.287^{\prime}$ & 2.5 & 0.3 & 1.3 \\
\hline & Babina & $45^{\circ} 18.090^{\prime}$ & $29^{\circ} 20.395^{\prime}$ & 2.5 & 0.5 & 1.3 \\
\hline & Roșca & $45^{\circ} 20.680^{\prime}$ & $29^{\circ} 23.302^{\prime}$ & 2.5 & 0 & 0 \\
\hline \multirow{6}{*}{$\begin{array}{l}\text { Roșu-Puiu } \\
\text { (LC 4) }\end{array}$} & Roşu & $45^{\circ} 03.507^{\prime}$ & $29^{\circ} 35.198^{\prime}$ & 1.3 & 0.5 & 1 \\
\hline & Roșuleț & $45^{\circ} 04.080^{\prime}$ & $29^{\circ} 36.801^{\prime}$ & 1.3 & 0.5 & 0.8 \\
\hline & Mândra & $45^{\circ} 02.082^{\prime}$ & $29^{\circ} 31.068^{\prime}$ & 1.3 & 0.5 & 1.3 \\
\hline & Puiu & $45^{\circ} 03.086^{\prime}$ & $29^{\circ} 28.372^{\prime}$ & 1.3 & 0.8 & 1.3 \\
\hline & Erenciuc & $45^{\circ} 00.669^{\prime}$ & $29^{\circ} 24.850^{\prime}$ & 2.5 & 0.5 & 1.3 \\
\hline & Tătaru & $45^{\circ} 18.090^{\prime}$ & $29^{\circ} 20.395^{\prime}$ & 1.5 & 1.5 & 1.3 \\
\hline
\end{tabular}

\subsection{Water samples collection.}

Water samples were taken in 2013 from the center of each lake, over the entire water column using a $5 \mathrm{~L}$ Schindler - Patalas device. Depending on the lake's depth, the water volume sampled varied between $5 \mathrm{~L}$ to $15 \mathrm{~L}$, corresponding to each meter of the lake water layer (1-3 $\mathrm{m})$. From the integrated water sample, a variable volume was filtered in situ (Table 1) using a vacuum filtration system with $250 \mathrm{~mL}$ capacity with a metal hand pomp (Nalgene, USA) and a glass fibers filter $\mathrm{GF} / \mathrm{F}, 47 \mathrm{~mm}$, with $0.45 \mu \mathrm{m}$ pore size (Whatman, UK) until this was saturated with biomass containing environmental DNA (eDNA). Each sample consisted of two GF filters replicates preserved separately in a zip bag full of silica beads to be kept dry until the DNA extraction. The same kind of eDNA samples were collected from Dâmbovița River to perform preliminary extraction tests to prevent wasting the lake samples.

Another set of eDNA samples were collected in March 2015 from the integrated water samples of the lakes: $30 \mathrm{~L}$ were filtered using a phytoplankton net with $35 \mu \mathrm{m}$ mesh size, and the obtained biomass was preserved in $200 \mathrm{~mL}$ tubes with ethanol 96\%. Freshwater culture of Tetradesmus obliquus (ex Scenedesmus obliquus) grown in the laboratory for 3-5 weeks on solid BG 11 medium or in WC liquid medium was also used as biomass for DNA extraction. For positive control, Microcystis aeruginosa PCC 7806 strain (obtained from the Pasteur Culture collection) was grown in the lab also in WC medium for 3-5 weeks and filtered on GF filters, and preserved similarly with the eDNA samples.

\subsection{DNA extraction.}

For eDNA extraction, Jena Bioscience Animal and Fungi DNA preparation Kit (JN), NucleoSpin genomic DNA purification kit (NS) were used for part of the DDBS lakes samples as well for Dâmbovița River samples in order to perform preliminary tests. The xanthogenate nucleic acid isolation method, based on a lab-made extraction buffer called xanthogenate-SDS (XS) was used for all the lakes samples and control strain. For freshwater culture extraction, 10-15 mL of liquid culture were centrifuged to obtain wet biomass, next used for the DNA extraction. The culture grown on a solid medium was directly taken from the Petri dish and used for DNA extraction. The XS extraction protocol used was adapted for environmental cyanobacteria from wet biomass preserved in alcohol and GF after Tillett and Neilan [29] and is summarized in Figure 3, and the recipe is detailed in Table 2 and Table S1. Briefly, 1/8 of each dried GF/F filter was incubated in $750 \mu \mathrm{L}$ of XS buffer for 3 hours and then centrifuged for 15 minutes at $22,000 \times \mathrm{g}$. The supernatant was mixed with $750 \mu \mathrm{L}$ phenol: chloroform: isoamyl alcohol (25:24:1) and centrifuged at $22,000 \times \mathrm{g}$; this process was repeated with the upper aqueous phase. The resulting supernatant was mixed with 1 volume isopropanol and 1/10 volume of $4 \mathrm{M}$ ammonium acetate, kept on ice for 20 minutes and centrifuged at 22,000 $\times \mathrm{g}$ 
for 15 minutes. The DNA pellet was washed with $1 \mathrm{~mL} 70 \%$ ethanol, centrifuged for 10 minutes at 22,000 $\times \mathrm{g}$, dried for 30 minutes under a sterile hood, and dissolved in $50 \mu \mathrm{L}$ sterile water. The same protocol was followed for extracting DNA from the reference strain from GF as well as for the filtered with a plankton net and centrifuged biomass, and fresh lab cultures of green algae. From the final DNA solution $(50 \mu \mathrm{L})$ of each sample, two sets of aliquots diluted ten times with sterile MiliQ water were made to avoid contamination in the further analysis of the samples. Extracted DNA was quantified by UV spectrophotometry using a NanoDrop ND2000 spectrophotometer (Thermo Fisher Scientific, USA) using $1 \mu \mathrm{L}$ of 1/10 diluted DNA. For the assessment of the nucleic acid purity, we measured the optical density (OD) (nm) for the $260 / 280$ and $260 / 230$ absorbance ratio.

\subsection{Molecular assay.}

The molecular assay was run on different kinds of samples: 1) fresh lab cultures both from liquid and solid medium, 2) filtered on GFs and dried with silica beads, or 3) filtered with phytoplankton net and preserved with alcohol. Before the environmental DNA (eDNA) extraction of DDBR lakes samples, we performed a series of tests in order to find the most suitable method and protocol to isolate as much DNA as possible. The setup consisted of parallel extraction from the liquid and solid medium of $T$. obliquus lab culture and wet (lab culture) and dry (from GF filters) algae biomass. For DNA extraction tests, commercial kits were used for comparison with a special lab-made extraction buffer (XS) (Table 2). In total, five series of tests were performed (Table 3). For PCR reaction, primers were selected from literature and different parameters were varied during the assays in order to optimize them. The final PCR protocol was (a) $95^{\circ} \mathrm{C}$ for $5^{\prime}$, (b) 35 cycles of the following: $95^{\circ} \mathrm{C}$ for $1^{\prime}, 60^{\circ} \mathrm{C}$ for $1^{\prime}$, $72^{\circ} \mathrm{C}$ for $1^{\prime}$ and (c) final elongation step at $72^{\circ} \mathrm{C}$ for $6^{\prime}$ with a pause at $4^{\circ} \mathrm{C}$. This protocol had to be changed and adapted depending on some pilot extractions and primers used. For the PCR amplification of cyanobacteria specific 16S rRNA gene, we used forward and reverse recommended primers [30, 31] with the amplicon size of 782 bp: $27 \mathrm{~F}$ AGAGTTTGATCCTGGCTCAG and 809R GCTTCGGCACGGCTCGGGTCGATA. For the PCR master mix (MM) MangoTaq DNA polymerase and MyTaq DNA Polymerase were used and all PCR reagents were from Bioline (London, UK). To reduce the PCR inhibitors $0.4 \mu \mathrm{g}$ $\mu \mathrm{L}^{-1}$ of bovine serum albumin (BSA) (GeneOn, Ludwigshafen, Germany) was also added. The MM used for cyanobacteria 16S rRNA amplification is presented in Table 3, with the mention that an excel sheet was designed to facilitate the preparation mix according to samples number (Figure 4). Products were analyzed on $1.5-2 \%$ agarose gel with $1 \times$ Tris-Borate EDTA (TBE) or $1 \times$ Tris base, acetic acid and EDTA (TAE) buffer. We used $5 \mu \mathrm{L}$ of each amplified DNA stained with $4 \mu \mathrm{L}$ ethidium bromide (EtBr) or $1.25 \mu \mathrm{L}$ of pegGREEN dye for visualization under UV with a photo capture system. To mark the right position of the amplicon, the Gene Ruler 100 bp Plus DNA Ladder (ThermoFisher Scientific, Waltham, MA, USA) was used with a range band from 100 to $3000 \mathrm{bp}$ (the band of interest being around $800 \mathrm{bp}$ ). 


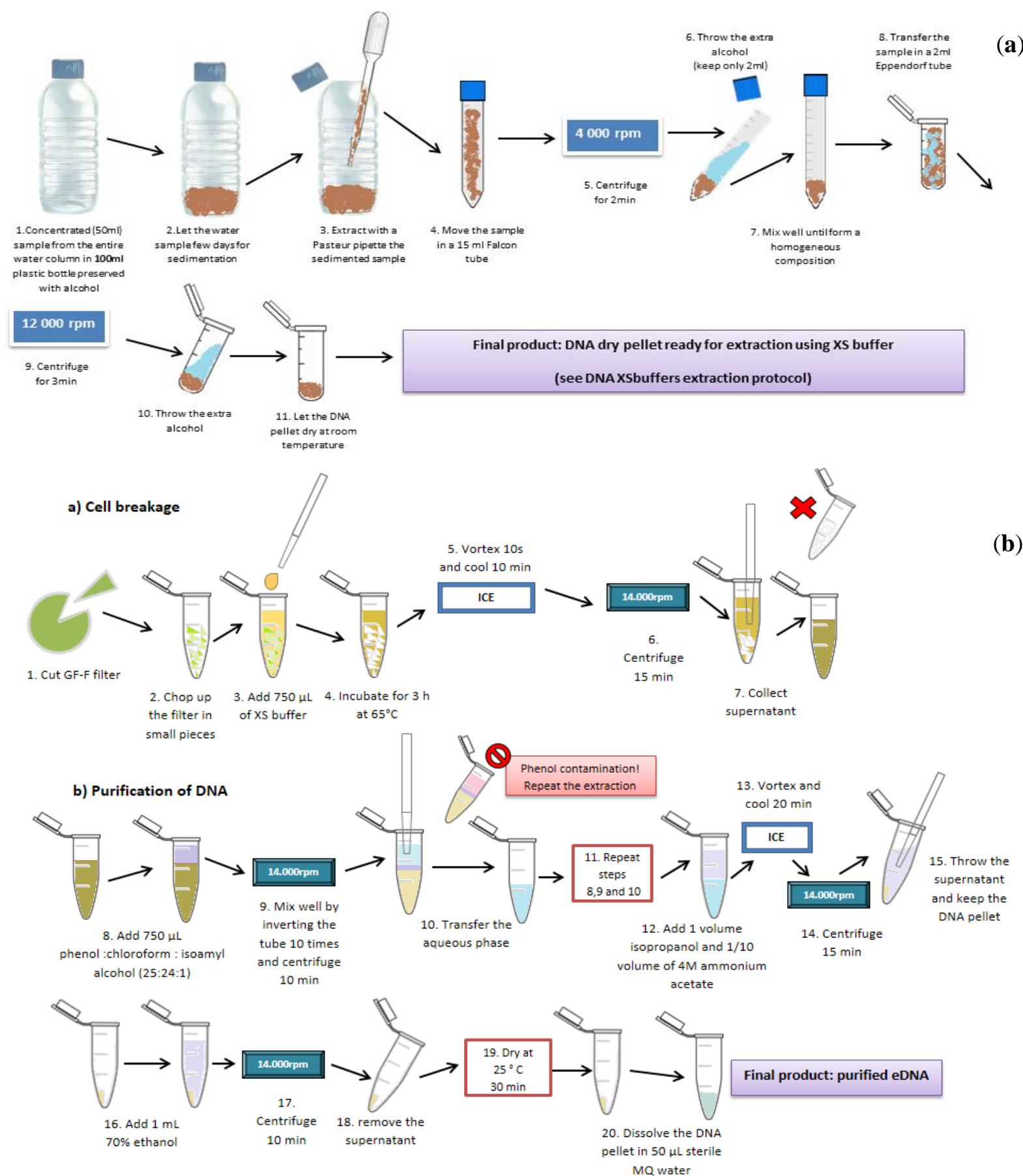

Figure 3. Schematic eDNA extraction protocol using lab-made extraction buffer based on potassium ethyl xanthogenate (XS buffer) for: (a) biomass preserved in alcohol; (b) GF filters full with biomass.

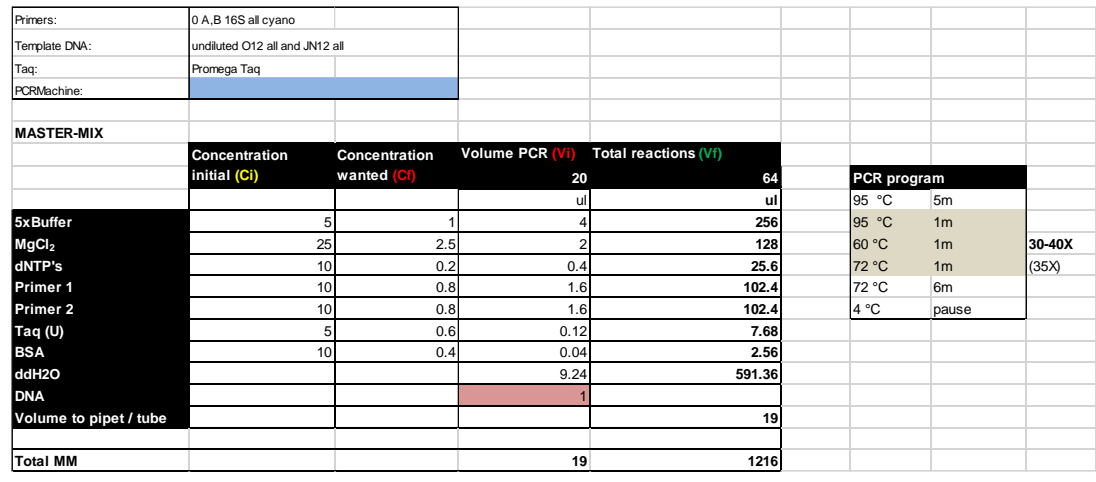

Figure 4. Optimized PCR program and the example of excel recipe calculator for the master mix used for $16 \mathrm{~S}$ rRNA amplification specific for all cyanobacteria species; for the PCR reaction, $1 \mu \mathrm{L}$ from the eDNA was used. https://biointerfaceresearch.com/ 
Table 2. Detailed recipe for reagent preparation for different volume of XS buffer (10-500 mL); for this study each time $50 \mathrm{~mL}$ of fresh buffer (bolded column) were prepared; the extraction procedure is detailed in Figure 3.

Recipe of XS buffer for cyanobacteria DNA extraction - $750 \mu \mathrm{L} / \mathrm{sample}$

$\begin{array}{l|l|l|l|l|l|l}\hline \multirow{2}{*}{\text { Reagent }} & \multirow{2}{*}{\begin{array}{c}\text { Molecular mass } \\$\cline { 3 - 7 }\end{array}} & \multicolumn{1}{c}{\text {$\left.(g mole L }{ }^{-1}\right)$}\end{array}$)$

Reagents and quantities used for the DNA extraction with XS

\begin{tabular}{l|l|l|l|l|l|l}
\multicolumn{7}{c}{ Reagents and quantities used for the DNA extraction with XS } \\
\hline $\begin{array}{l}\text { Ammonium acetate (4 M) } \\
\text { 1/10/sample }\end{array}$ & 77.08 & $3.0832 \mathrm{~g}$ & $\mathbf{1 5 . 4 1 6} \mathbf{g}$ & $30.832 \mathrm{~g}$ & $\mathbf{6 1 . 6 6 4 \mathrm { g }}$ & $154.16 \mathrm{~g}$ \\
\hline $\begin{array}{l}\text { Isopropanol 100\% } \\
\text { 1 vol./sample }\end{array}$ & - & $\sim 8 \mathrm{~mL}$ & $\sim \mathbf{4 0} \mathbf{~ m L}$ & $\sim 80 \mathrm{~mL}$ & $\sim 160 \mathrm{~mL}$ & $\sim 400 \mathrm{~mL}$ \\
\hline $\begin{array}{l}\text { Phenol-chloroform-isoamyl } \\
\text { alcohol }(25: 24: 1 \mathrm{v} / \mathrm{v})\end{array}$ & - & $\sim 8 \mathrm{~mL}$ & $\sim \mathbf{4 0} \mathbf{~ m L}$ & $\sim 80 \mathrm{~mL}$ & $\sim 160 \mathrm{~mL}$ & $\sim 400 \mathrm{~mL}$ \\
$750 \mu \mathrm{l} /$ sample & & & & &
\end{tabular}

*Formula used for calculation is $\mathrm{md}=\mathrm{Cm} \mathrm{M} \mathrm{V}$, where: $\mathrm{md}=$ mass to be dissolved, $\mathrm{Cm}=$ molar concentration, $\mathrm{M}=$ molecular mass, and $\mathrm{V}=$ the solution volume. A calculation example for XS buffer preparation reagents can be found in supplementary material Table $\mathrm{S} 1$.

\section{Results and Discussion}

\subsection{DNA isolation preliminary tests.}

All the tests are described in Table 3 as follows:

Test 1: JN protocol (a) and (b) from JN and liquid or solid matrix?

The commercial extraction kit provided by Jena Bioscience Animal and Fungi DNA preparation Kit $(\mathrm{JN})$ offers two different types of protocol for extraction: one also used for animal tissues (a) and the second one adapted for fungi (b). For this test fresh algae biomass of T. obliquus (TO) cultivated both in WC liquid medium and on BG 11solid medium was used.

Test 2: JN short or long time incubation period and dry or wet matrix?

The second round of tests was performed to evaluate the DNA extraction efficiency at different incubation periods, 3 hours compared to overnight (12 hours) from two types of matrix: wet, the same as in test 1 , and dried biomass obtained by filtration of water from Dâmbovița River on GF/F (1/4 of the filter was used for the DNA extraction).

Test 3: NS short or long time incubation period and dry or wet matrix?

The third round of tests was done as same as test 2 but this time using NS kit for wet and dried biomass as a matrix for DNA extraction but also for three of our DDBS eDNA samples (1/8 of GF) chosen from lakes belonging to different lake complexes: lake Puiu from LC4, lake Cuibul cu Lebede from LC2 and lake Lungu from LC3.

Test 4: JN versus NS extraction.

This test compared the two commercial kits in DNA extraction efficiency and purity after the overnight incubation period. For that, wet and dried biomass were used as matrix for 
DNA extraction and two of our DDBS eDNA samples (1/8 of GF): lake Cuibul cu Lebede from LC2 and lake Lungu from LC3.

Test 5: kits versus XS.

The last test consisted of the comparison of the commercial kits with the XS buffer from eDNA samples filtered on GF and incubated overnight for cell lysis.

Table 3. Series of tests performed prior to DNA isolation of DDBR eDNA samples in order to select the best protocol; DNA concentration is in $\mathrm{ng} \mu \mathrm{L}^{-1}$.

Test 1: different buffer lysis and matrix $(J N)$

\begin{tabular}{|c|c|c|c|c|}
\hline & & & & \\
\hline DNA sample & protocol (a) & $260 \backslash 280$ & protocol (b) & $260 \backslash 280$ \\
\hline $\mathrm{TO}_{\text {liquid }} \mathbf{1}$ & 201.1 & 1.62 & 81 & 1.74 \\
\hline $\mathrm{TO}_{\text {solid }}$ & 16.7 & 1.74 & 13 & 1.37 \\
\hline \multicolumn{5}{|c|}{ Test 2: different incubation time and matrix $(J N)$} \\
\hline DNA sample & $\begin{array}{l}\text { incubation } \\
3 \text { hours }\end{array}$ & $260 \backslash 280$ & $\begin{array}{l}\text { incubation over } \\
\text { night }\end{array}$ & $260 \backslash 280$ \\
\hline $\mathrm{TO}_{\text {liquid }} \mathbf{2}$ & 9 & 2.64 & 12.3 & 1.85 \\
\hline $\mathrm{DB}_{\text {filter }} \mathbf{1}$ & 241.2 & 2.11 & 492.7 & 2.08 \\
\hline $\mathrm{DB}_{\text {filter }} 2$ & 163.9 & 2.16 & 335.5 & 2.06 \\
\hline $\mathrm{DB}_{\text {filter }} \mathbf{3}$ & 344.4 & 2.12 & 437.8 & 2.05 \\
\hline $\mathrm{DB}_{\text {filter }} 4$ & 234 & 2.10 & 329.3 & 2.09 \\
\hline $\mathrm{DB}_{\text {filter }} \mathbf{5}$ & 784.6 & 2.01 & 1734.8 & 2.05 \\
\hline $\mathrm{DB}_{\text {filter }} \mathbf{6}$ & 351 & 2.10 & 386.5 & 2.09 \\
\hline \multicolumn{5}{|c|}{ Test 3: different incubation time and matrix $(N S)$} \\
\hline DNA sample & $\begin{array}{l}\text { incubation } \\
3 \text { hours }\end{array}$ & $260 \backslash 280$ & $\begin{array}{l}\text { incubation over } \\
\text { night }\end{array}$ & $260 \backslash 280$ \\
\hline $\mathrm{TO}_{\text {liquid } 3}$ & 45.6 & 2.12 & 47 & 1.95 \\
\hline $\mathrm{DB}_{\text {filter }} 7$ & 74.3 & 1.98 & 104.2 & 2.11 \\
\hline LC4PU & 12.5 & 2.01 & 53.8 & 2.02 \\
\hline LC2CL & 8.7 & 1.42 & 14.4 & 1.65 \\
\hline LC3LU & 13.9 & 1.58 & 19.1 & 2.38 \\
\hline
\end{tabular}

Test 4: different extraction kits and matrix (JN versus $N S)$

\begin{tabular}{l|ll|l|l}
\hline DNA sample & JN & $260 \backslash 280$ & NS & $260 \backslash 280$ \\
\hline $\mathrm{TO}_{\text {liquid }} \mathbf{2}$ & 12.3 & 1.85 & 45.6 & 2.12 \\
\hline $\mathrm{DB}_{\text {filter }} \mathbf{8}$ & 154.9 & 2.11 & 246.35 & 1.98 \\
\hline LC2CL & 3.5 & 2.78 & 14.4 & 1.65 \\
\hline LC3LU & 3.9 & 1.84 & 19.1 & 2.38 \\
\hline
\end{tabular}

Test 5: commercial kits versus lab-made buffer $(J N, N S, X S)$

\begin{tabular}{l|ll|l|l}
\hline DNA sample & JN & NS & XS & $260 \backslash 280$ \\
\hline DB filter 8 & 154.9 & 246.35 & 934.5 & 1.63 \\
\hline LC2CL & 3.5 & 14.4 & 41.4 & 1.59 \\
\hline LC3LU & 3.9 & 19.1 & 49.4 & 1.76 \\
\hline
\end{tabular}

*TO=T. obliquus, $\mathrm{DB}=$ Dâmbovița River, $\mathrm{LC} 2 \mathrm{CL}=$ Cuibul cu Lebede lake, LC3LN=Lung lake, LC4PU=Puiu lake, JN= Jena Bioscience Animal and Fungi DNA preparation Kit, NS= NucleoSpin genomic DNA purification kit and $\mathrm{XS}=$ xanthogenate nucleic acid isolation method

\subsection{DNA isolation from DDBR shallow lakes.}

For all the eDNA samples from DDBR we extracted DNA both with commercial kits and the XS buffer in order to highlight the difference on a larger set of samples (from 26 lakes) collected in different seasons. In Figure 5, the DNA concentration isolated from 1/8 part of GF is exposed comparative for both extraction methods. The quality of the extracted DNA was evaluated by measuring the OD express as 280/260, and 260/230 absorbance ratio and the mean values for spring and summer are given in Table 4. The total genomic DNA from GF of DDBR shallow lakes over all three seasons is given in Figure 6, and for the samples preserved in alcohol (Table S2) the average DNA concentration was $350 \mathrm{ng} \mu \mathrm{L}^{-1}$ (varied between 103 - 793 ng $\mu \mathrm{L}^{-1}$ ), and $\mathrm{OD}$ at $260 / 280$ was 1.64 and at $260 / 230$ was 1.47 . 


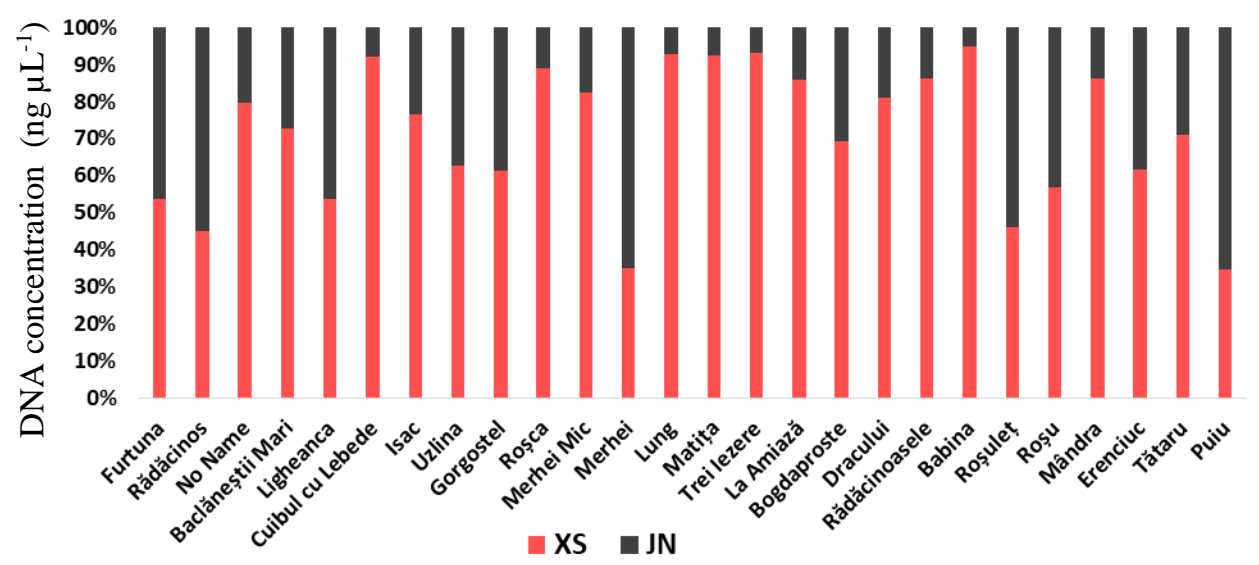

Figure 5. Comparison of total genomic DNA from Danube Delta shallow lakes in July 2013 (exception Roșca that was sampled May) extracted with XS buffer (XS) and using Jena Bioscience Animal and Fungi DNA preparation Kit $(\mathrm{JN})$.

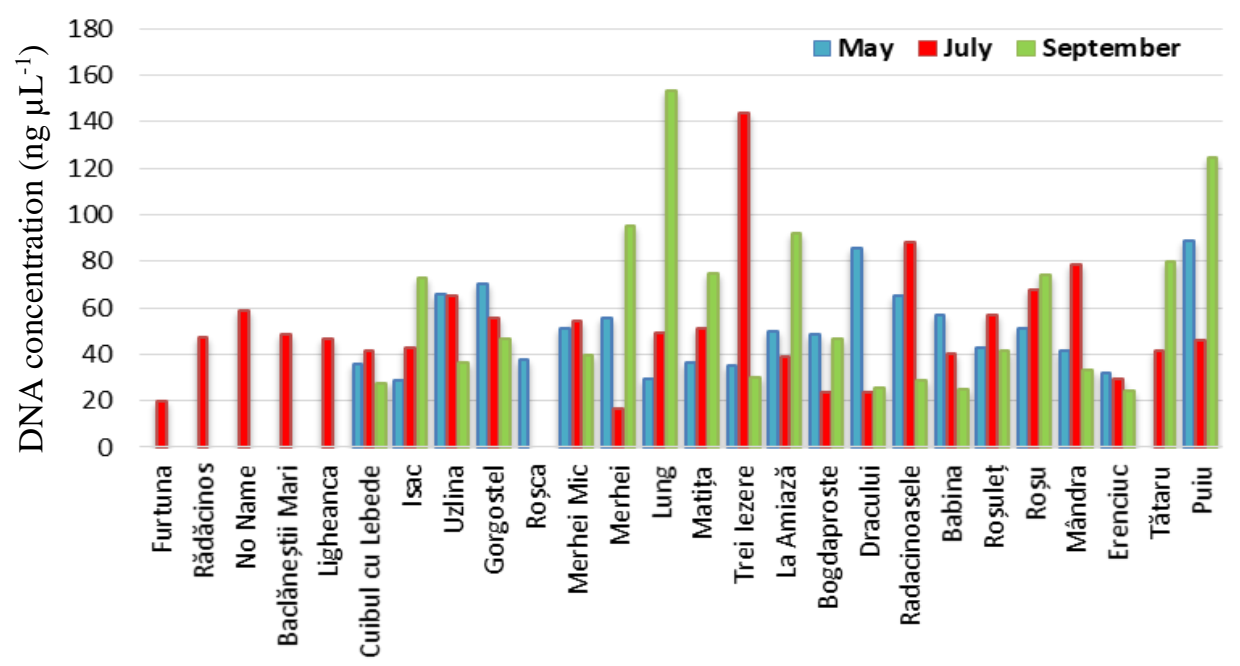

Figure 6. Total genomic DNA from Danube Delta shallow lakes in 2013; for the extraction with XS buffer only $1 / 8$ part of the GF full with biomass was used. Not all lakes were sampled in all three seasons, from where the missing data.

Table 4. Comparative mean values for the OD ratio from DDBR shallow lakes DNA samples over two seasons obtained with two different extraction methods.

\begin{tabular}{l|l|l|l|l}
\multirow{2}{*}{$\begin{array}{l}\text { Extraction } \\
\text { season }\end{array}$} & \multicolumn{4}{|l}{ NanoDrop measurement of OD ratio } \\
\cline { 2 - 5 } & $\mathbf{2 6 0 / 2 8 0}$ & $\mathbf{2 6 0 / 2 3 0}$ & \\
\cline { 2 - 5 } & May & July & May & July \\
\hline JN & 2.045 & 2.0464 & 1.296 & 1.3576 \\
\hline $\mathrm{XS}$ & 1.703 & 1.7152 & 2.0065 & 1.8184
\end{tabular}

\subsection{PCR protocol optimization.}

For PCR optimization, we selected and tested the programs and recipes found in the literature (Table 5). The selection criteria consisted of choosing the paper in which scientists used the same primers specific for cyanobacterial 16S rRNA. The annealing temperature was optimized empirically by performing PCRs with 30 to 40 incubation cycles, denaturation, and primers annealing at 30", 1' and 1' and 30". To optimize the PCR reaction MM three sets of tests were performed on our DDBS lakes samples as follow: 
Test 1 - PCR protocol used was according to the literature: $0.5 \mathrm{mM}$ of $\mathrm{MgCl}_{2}$ and 40 cycles (Figure 7 (a)),

Test $2-2 \mathrm{mM}$ of $\mathrm{MgCl}_{2}$ and 40 cycles (Figure $7 \mathrm{~b}$ ), and

Test $3-2.5 \mathrm{mM}$ of $\mathrm{MgCl}_{2}$ and 35 cycles (Figure 7c).

After the PCR protocol optimization, several tests were run to verify the presence of 16S rRNA region specific for cyanobacteria in our samples (Figure 8).

Table 5. Comparative PCR programs and master mix (MM) recipes tested.

\begin{tabular}{|c|c|c|c|c|}
\hline Reference/PCR program & {$[30]$} & {$[31]$} & {$[32]^{1}$} & Our study \\
\hline Initial denaturation & $94^{\circ} \mathrm{C}$ for $4^{\prime}$ & $92^{\circ} \mathrm{C}$ for $2^{\prime}$ & $92^{\circ} \mathrm{C}$ for $2^{\prime}$ & $95^{\circ} \mathrm{C}$ for $5^{\prime}$ \\
\hline$\#$ of cycles & 30 & 35 & 30 & $30-40$ \\
\hline Denaturation & $94^{\circ} \mathrm{C}$ for $20^{\prime \prime}$ & $94^{\circ} \mathrm{C}$ for $10^{\prime \prime}$ & $92^{\circ} \mathrm{C}$ for $20^{\prime \prime}$ & $\begin{array}{l}95^{\circ} \mathrm{C} \text { for } \\
30^{\prime \prime}-1 ': 30^{\prime \prime}\end{array}$ \\
\hline Primer annealing & $50^{\circ} \mathrm{C}$ for $30^{\prime \prime}$ & $60^{\circ} \mathrm{C}$ for $20^{\prime \prime}$ & $50^{\circ} \mathrm{C}$ for $30^{\prime \prime}$ & $\begin{array}{l}60^{\circ} \mathrm{C} \text { for } \\
30^{\prime \prime}-1^{\prime}: 30^{\prime \prime}\end{array}$ \\
\hline Strand extension & $72^{\circ} \mathrm{C}$ for $2^{\prime}$ & $72^{\circ} \mathrm{C}$ for $1^{\prime}$ & $72^{\circ} \mathrm{C}$ for $1^{\prime}$ & $72^{\circ} \mathrm{C}$ for $1^{\prime}$ \\
\hline Final extension & unprovided & $72^{\circ} \mathrm{C}$ for $5^{\prime}$ & $72^{\circ} \mathrm{C}$ for $7^{\prime}$ & $72^{\circ} \mathrm{C}$ for $6^{\prime}$ \\
\hline Pause & $4^{\circ} \mathrm{C}$ & $4^{\circ} \mathrm{C}$ & $4^{\circ} \mathrm{C}$ & $4^{\circ} \mathrm{C}$ \\
\hline $\begin{array}{l}\text { Reference/ } \\
\text { PCR MM }\end{array}$ & {$[30]$} & [31] & [32] & Our study \\
\hline Buffer $(\mu \mathrm{L})$ & unprovided & unprovided & 1 & 1 \\
\hline $\mathrm{MgCl}_{2}(\mathrm{mM})$ & unprovided & unprovided & 2.5 & 2.5 \\
\hline dNTP's (mM) & unprovided & unprovided & 0.2 & 0.2 \\
\hline Primers $\left(\mathrm{pM} \mu \mathrm{L}^{-1}\right)$ & unprovided & unprovided & 0.2 & 0.3 \\
\hline Taq (units) & unprovided & unprovided & 0.5 & 1 \\
\hline $\mathrm{BSA}\left(\mu \mathrm{g} \mu \mathrm{L}^{-1}\right)$ & unprovided & unprovided & - & 0.4 \\
\hline
\end{tabular}

*MM=PCR master mix, dNTP's= deoxyribonucleotide triphosphate, Taq= Taq DNA Polymerase, BSA= bovine serum albumin.

\subsubsection{Different matrix and DNA extraction kits.}

Testing the DNA extraction methods is an important and mandatory step no matter what the matrix is, as previous studies showed [34, 20], since this represents a critical step in cultureindependent bacterial profiling [33]. Even if many different protocols and commercial kits have been developed for DNA extractions from environmental samples [13] there is still a lack of reliable techniques for DNA extraction as well for RNA isolation for several types of cyanobacteria [22]. Almost all commercial kits significantly improved the final purification product for most bacteria but not for cyanobacteria [19].

Therefore, according to our first hypothesis, we evaluated whether using different biomass matrix and extraction methods, the quantity and quality of algae/cyanobacteria extracted DNA from DD could be improved. We showed that biomass extracted from liquid medium instead of biomass obtained from solid culture medium coop better with the extraction buffer specific for tissues provided by the commercial kit from Jena and not the one specific for fungi (Table 3). Since the matrix effect was reduced by using the same samples, the variations in the data can be attributed exclusively to the effects of extraction methods, as other scientists remarked [11]. This was an important step since one needs to know from which matrix one can extract adequate DNA if proceed further with the cyanobacteria or algae isolation and PCR amplification as well. Preliminary tests were made using a green alga from Pasteur collection in order to minimize the problem of DNA extraction given by the cyanobacteria cell envelope. 


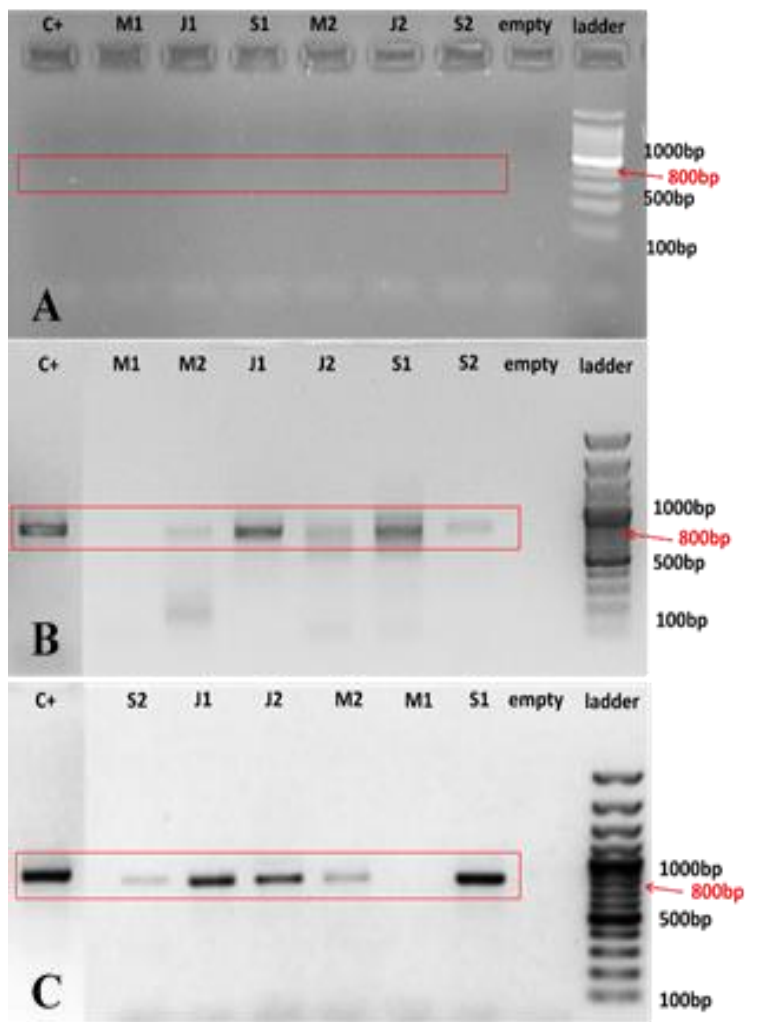

(a)

(b)

(c)

Figure 7. Electrophoresis gels (1.5\% agarose, $1 \times \mathrm{TAE}$, dyed with EtBr, ran at $50 \mathrm{~V}$ for $40^{\prime}$ ) used for protocol optimization tests performed with MyTaq and $5 \mu \mathrm{L}$ PCR product (expected amplicon size was $782 \mathrm{bp}$ corresponding to the 16sRNA region specific for cyanobacteria) and using: (a) $1.5 \mathrm{mM}$ of $\mathrm{MgCl}_{2}$ and 30 cycles for PCR program; (b) $2 \mathrm{mM}$ of $\mathrm{MgCl}_{2}$ and 40 cycles for PCR program; (c) $2.5 \mathrm{mM}$ of $\mathrm{MgCl}_{2}$ and 35 cycles for PCR program. Random selection was made from May (M1, 2) July (J1, 2), and September (S1, 2) from eDNA lakes samples. PCR product was amplified in 5 of the 6 samples tested, and the intensity of the band varied according to the DNA quantity.

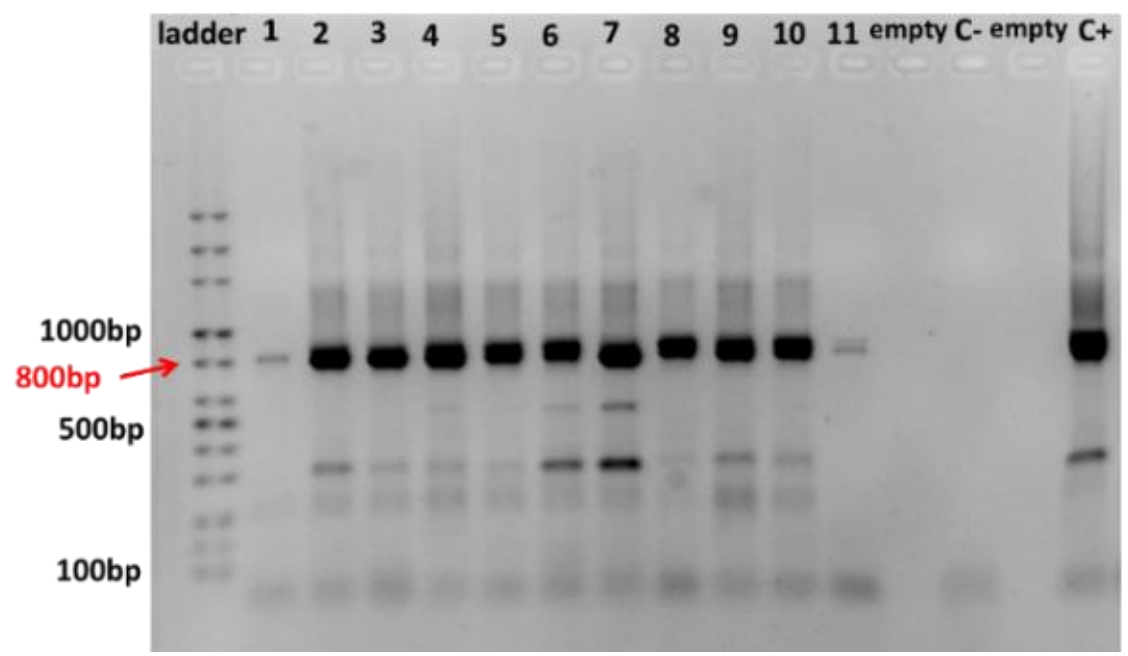

Figure 8. Electrophoresis gel ( $2 \%$ agarose, $1 \times$ TBE buffer, dyed with pegGREEN directly in the gel, ran at 120

$\mathrm{V}$ for 50') performed with MangoTaq and $20 \mu \mathrm{L}$ PCR product (expected amplicon size was $782 \mathrm{bp}$ corresponding to the 16sRNA region specific for cyanobacteria) and using the optimized PCR protocol with

BSA (Figure 7c). Random eDNA from lakes sampled in autumn (1-11) and positive control DNA of $M$. aeruginosa PCC 7806 were used for tests. PCR product was amplified in all the samples, with the mention that in 11 a very thin band was noted meaningless DNA; also unspecific bands are present.

However, due to the high variability of cyanobacteria shape and size (unicellular, colonial, or filamentous), various cell lysis methods are required [22]. Therefore in the second and third set of tests, we compared the incubation period necessary for cell lysis and the buffers 
from two different extraction kits, this time also from eDNA sampled with GF. As expected, more DNA was obtained after an overnight incubation period. Also, filtered samples were easier to be long-time stored, and the DNA quantity was higher since this method allowed to concentrate the biomass from a higher water volume. Further, comparative tests using two different commercial kits revealed that better DNA values were obtained using NucleoSpin kit, especially from the Danube Delta eDNA samples.

Still, a comparative study in which six DNA extraction kits were tested revealed that PCR inhibitors were present in all DNA solutions extracted [34]. Hence, a completely efficient method to obtain a higher quantity of DNA and get rid of all the inhibitors at the same time does not exist. However, another serious problem is that DNA isolation and purification efficiencies vary considerably from one species to another [19]. Similar to DNA extraction kits, the choice of sample storage buffer has been shown to influence the detected bacterial community [33]. Therefore, one needs to be careful when using buffers that contain ETDA since this can be found commonly in some elution buffers of commercial kits, and in some certain concentrations, it may deplete magnesium ions and thus inhibit DNA polymerase activity [35]. Also, commercial kits are expensive when many samples need to be processed, while the lab-made buffer for DNA extraction represents a more economical extraction method if the efficiency criteria are required. Within this study, we tested both several commercial kits and a lab-made buffer for the cyanobacteria extraction since it was proven that the extracted DNA concentration varied significantly between the commercial kits [20], which is also in line with our findings (Table 3, test 5).

\subsubsection{Commercial DNA extraction kits versus lab-made XS buffer.}

It is already known that the efficacy of sample processing and DNA extraction may be affected by most of the known organic compounds, e.g., bile salts, urea, phenol, ethanol, polysaccharides, sodium dodecyl sulfate (SDS), as well as different proteins [35]. However, the XS protocol has been previously shown to give high-quality genomic DNA, not only from cyanobacteria but also from other microorganisms [29]. Therefore, in order to test the lab-made buffer for the XS extraction method and in parallel the above-mentioned kits, we selected also few samples from the Danube Delta eDNA samples as following: lake Puiu from LC4, considered with high abundance of cyanobacteria, lake Cuibul cu Lebede from LC2 chosen for fewer cyanobacteria and lake Lungu from LC3 considered with a high quantity of inhibitors (Table 3).

It can be easily noticed in Figure 5 that when using the XS extraction method, substantially more total genomic DNA was obtained than when the commercial DNA extraction kit Jena Bioscience Animal and Fungi DNA preparation Kit was used. Thus we decided to use the lab-made buffer, fresh each time, to assure a high quantity of cyanobacteria DNA for our total genomic DNA samples. Only four out of 26 lakes did not follow the tendency of results, namely lakes Rădăcinos, Merhei, Roșuleț, and Puiu, but the eDNA quantity was more than enough to be used for PCR amplification. We cannot explain for sure this unusual result, an explanation could be that during the extraction protocol, part of the DNA pellet did not totally dissolve, or, most probable, during the DNA quantification with the NanoDrop we did not manage to mix well the sample, and part of the eDNA remained attached in the bottom part of the tube, undissolved completely. Surprisingly, Lungu lake considered with a high quantity of inhibitors, had the highest efficiency with XS method (Figure 5); therefore, we performed all the extraction using this method. However, our DNA pellets after XS isolation 
were often brownish in color, suggesting the presence of humics [5]. Even so, our samples still produce clear band even from smaller DNA fragments in PCR amplification using the universal primers for $16 \mathrm{~S}$ rDNA gene. Therefore this extracted DNA can be successfully applied in different molecular biology methods as other researchers experience [13].

We also found one paper that reported a significantly lower amount of DNA isolated with the phenol-chloroform method compared with the commercial kit used [20]. Contrary, this was not the case with our tests, no matter the matrix that we used for extraction, ten times more DNA values were obtained using this protocol comparing with the commercially kits (Figure 5) and our result was not an isolated case since other scientists experienced similar results when using a phenol-chloroform based extraction method [36]. For example, it has been demonstrated that filamentous cyanobacteria respond better to phenol and SDS extraction [19] even if the SDS inhibits the extraction, or that phenol-chloroform extraction is the most efficient in obtaining good quality DNA even from matrix preserved with paraffin [10]. For this tests we considered Cuibul cu Lebede as being the lake with less cyanobacteria and Lungu and Puiu with cyanobacteria blooms (Table 3). The best method seems to comprise the filtration of water samples on GF, extraction of DNA (from $1 \backslash 8$ of GF) using XS buffer to obtain a higher amount of DNA comparing with commercial kits (Table 3, Figure 5), and 1/10 dilution of DNA before PCR (data not shown), as well as the reduction of the amount of primers and utilization of BSA to attenuate the inhibitory effect (Figure 8). The most probable explanation why XS methods was more efficient is that some strains of cyanobacteria might be harder to lyse than others especially filamentous ones, that are abundant in our samples, and commercial kits extraction columns and buffers are not as efficient as XS. If the cells are not completely lysed (these can easily be observed once the color changes and the extraction buffer becomes more intense), extra vortex and incubation of the samples should be performed until complete cell lysis. One can even add some silica beads and vortex the samples repeatedly and check under microscope to see if the cells lyse or filaments break up, otherwise continue to vortex as long as it is necessary.

DNA quality. In order to establish the quality of each extracted DNA sample, we measured it spectrophotometrically using a NanoDrop instrument since the absorbance profile was useful for detecting contaminants that could severely affect the DNA purity [11]. Therefore, the A260/A280 and A260/A230 ratios for all extractions must be measured to describe the DNA purity besides the quantity [37]. Ideally, the pure and undegraded genomic DNA must be characterized by an A260/A280 ratio of about 1.8, especially in the case of commercial kits, and an A260/A230 ratio of about 2.0 [19].

For our samples (Table 4) the mean value of the A260/280 ratio was 1.7, which means that our DNA was pure enough, but slight traces of proteins resulted during the extraction procedure of XS method, while the kit used managed to be protein-free. In similar studies, for example, the A260/A280 ratio between 1.93 and 2.27 indicates insignificant levels of contamination, while a ratio from 1.6 to 1.8 indicates that the extracted DNA had high purity with the absence of proteins and phenols [11].

In order to take into consideration also the influence of the local environmental conditions on the eDNA samples, we compared both spring OD values (flooding period with a high quantity of sediment/humic acid) with the summer ones, considered mostly with cyanobacteria/alga mass development, therefore with polysaccharides presence. In the case of the XS method, the ratio was nearly 1.7 indicating the sufficient removal of protein contaminants [13]. Even for different species, the DNA extraction efficiency may vary, being 
reflected by the A260/A280 as it has been already shown: 1.84-2.02 for Anabaena sp., 1.882.12 for Nodularia spumigena, and 1.75-1.90 for Nostoc sp. [19]. For the A260/A230 ratio instead, kits did not manage to clean our samples for contaminants either from the environment or from the buffers. On the other hand, with the XS method, better results were obtained even if this implied a high risk of phenol contamination, meaning that the genomic DNA extracted by us was suitable for molecular assay.

\subsubsection{DNA isolation from DDBR shallow lakes.}

Since in DDBR is highlighted a strong seasonality regarding the phytoplankton distribution [38], this tendency was also found in the eDNA quantity extracted from our samples during spring, summer, and autumn (Figure 6). As expected, higher values were registered both in July and September since, according to our data, we found cyanobacteria mass development in some lakes as well in September or even in May [21]. The DNA concentration highlighted this tendency as well, making the XS method a very reliable one for this kind of study. More, in order to be sure that the high quantity of DNA was also purified enough, we analyzed the OD ratio mean values for all samples (Table 4). In the case of samples that were preserved with alcohol (Table S2), the A260/A280 and A260/A230 ratios were lower, meaning that there was protein contamination, DNA being more degraded, and that the other inhibitors could interfere more with the PCR.

\subsubsection{PCR protocol optimization.}

PCR reaction can fail due to the inhibitors that are very common, especially in environmental samples. The PCR inhibitors represent a diverse group of substances such as proteins, salts, and polysaccharides [11], that act at different steps of the diagnostic procedure from sampling until the amplification of the nucleic acids. In our samples from Danube Delta shallow lakes we expected to find the widely occurring freshwater environmental inhibitors represented by: fulvic acids from dead biomass and sediments that copurify with DNA and inhibit PCR and restriction digestion of DNA [5, 22, 35], humic acids that inhibit PCR and interact with the polymerase preventing the enzymatic reaction even at low concentrations [35, $39,22]$, as well as the cyanobacterial polysaccharides that may disturb the enzymatic process [35]. Calcium salts represent an example of inorganic substances with inhibitory effects on the PCR and polymerase activity and even the wall of the reaction tubes [35], powder from gloves [40] or different other salts (e.g., sodium chloride or potassium chloride), detergents and EDTA [41] may affect the efficacy of sample processing. Therefore is crucial to select an appropriate extraction method to minimize the inhibitions during sample processing.

In order to annihilate the effect of the inhibitors in the samples processed by us, especially those from humic acids, we added in our PCR mix bovine serum albumin (BSA) in a concentration of $400 \mathrm{ng} \mathrm{mL}-1$ as other studies recommended [34, 39]. Even if this additive is used to boost PCR, it is not effective in the case of SDS, EDTA, and calcium presence [41] and, in our samples, we had them all. BSA, like DMSO is recommended as well for difficult template GC-rich (>60\%) like our samples to improve its availability for hybridization and reduces nonspecific binding [42].

It was also demonstrated that the bacterial DNA contamination in the Taq polymerase exists and could often give false-positive results, especially when working with 16S primers [43]. This is due mostly to the laboratory environment during the protein purification. 
Therefore, we can exclude this possibility in our case since we used specific primers for cyanobacteria. Another potential cause for the bias in the analysis is that the use of $16 \mathrm{~S}$ primers may favor certain bacterial strains [33], but in our first assay attempt, we did not find any bands; hence the problem was elsewhere.

Nevertheless, we need to take into consideration that the high presence of calcium ions can give a competitive binding to the template and inhibit the PCR reaction, but it might be compensated by the addition of magnesium ions into the MM [35]. To reduce the inhibitory influence, we also diluted the DNA and prepared 1/10 aliquots from the initial eDNA since this method was proven to be widely applied for the dilution of PCR inhibitors [44]. Further, the initial PCR programs and master mix recipes found in others papers were tested and optimized for our DDBR eDNA samples (Table 5). First, the PCR program was modified starting from the one proposed by Neilan and his team in 1997 [30]. In order to improve the amplification and to obtain clearer bands, we added more cycles to the initial PCR protocol since other scientists proceeded the same to improve the amplification of low DNA concentration samples in the case of 16S rRNA gene amplification [33]. Thus, when assayed the same protocol at 35 and 40 cycles (Figure 7), clear bands were obtained at 35 cycles (Figure 7c) compared to 30 cycles (Figure 7a), while 40 cycles were proven to be too much (Figure 7b). Results were maintained for diluted DNA samples as well.

However, the annealing of the primers to the DNA template may be disturbed by certain PCR inhibitors [45]. Therefore, we also tested the diluted aliquots. For example, calcium mostly resulted from the high diatoms presence in our samples, competed as a cofactor instead of $\mathrm{MgCl} 2$ binding to our template, resulting in zero amplification for our samples (Figure 7a). In order to compensate, we gradually increased the $\mathrm{MgCl} 2$ concentration during our tests, from 1.5 to $2.5 \mathrm{mM}$ (Figures $7 \mathrm{~b}$ and $\mathrm{c}$ ), with the recommendation that the maximum concentration is the most useful.

Other studies also tested different agarose gels concentration $(1,1.5$, and $2 \%)$, and the best results were observed at the lowest concentration [11], which was in concordance with our results. Also, the addition of too much cycles to the PCR program was proven to be not efficient for the amplification since this create chimeric structures as can been seen in the Figure 7 (b). This supports the assumption that lower numbers of cycles are favourable for amplicon sequencing [33]. All the tested samples were amplified with the optimized protocols, even those with a very low DNA quantity of cyanobacteria (Figure 8), thus the protocols were useful for the analysis of cyanobacteria from DDBR.

\section{Conclusions}

For studying freshwater cyanobacteria, especially from Danube Delta Biosphere Reserve shallow lakes, the best eDNA sampling method is using GF saturated with biomass, dried with silica beads and stored for the long term period in the lab. Our recommendation is to use only a small part of the filter full with eDNA since according to our tests, $1 / 8$ of the filter was enough. The best extraction method was proven to be the lab-made buffer based on potassium ethyl xanthogenate (XS). It should be always prepared in small quantities according to the samples number $(10-50 \mathrm{~mL})$ since is mandatory to be prepared fresh, in the same day or with a day before, in order to ensure a high quantity and quality of the extracted DNA. The method must be adapted for each sample apart (meaning that the aqueous volume may differ) to avoid phenol contamination, depending on DNA quantity which may vary from lakes to lakes but mostly seasonally: in spring we had less DNA and in summer considerable more, for 
instance. This means that not all the time the isopropanol volume that need to be added will be the same for all the samples in the same extraction. We strongly recommend to pay attention on this during extraction process. For liquid samples, at least $15 \mathrm{~L}$ of water must be filtered through a phytoplankton net to obtain enough biomass for DNA extraction, if there is no possibility to use in situ a filtering system with a GF of maximum $45 \mu \mathrm{m}$ pore size. We also recommend to dilute the extracted DNA ten times and prepare at least two sets of aliquots and to use only a small amount of primers (below $0.3 \mu \mathrm{L} / \mathrm{sample}$ ) for PCR reaction, since we had primers residues. Also, never use less than 1 unit of Taq per sample as a general rule. The PCR parameters must be set different as well; the best protocol is to use 35 cycles and vary the $\mathrm{MgCl}_{2}$ concentration when is necessary, but not lower than $2 \%$ and add BSA since the inhibitors are present in high percent in shallow lakes. Method optimization was an essential step, the findings showing that a combination of various working protocols and reagents is needed to ensure obtaining of as large DNA quantities (and its quality) as possible. Work on further DNA purification, creation of clone library and lakes classification based on occurrence of genes with potential to release toxins is in progress.

\section{Funding}

This research was funded by the Swiss Enlargement Contribution (IZERZ0 - 142165, "CyanoArchive") in the framework of the Romanian-Swiss Research Programme.

\section{Acknowledgments}

The authors transmit their special thanks to CyanoArchive Project team and Sulina field team for all the support during the sampling trips, to dr. Piet Spaak, dr. Francesco Pomati, dr. Beatrice Kelemen, acad. dr. Octavian Popescu and dr. Iulia Lupan for all the help and supervising, to dr. Marie Eve Monchamp, dr. Christoph Tellenbach, dr. Bogdan Drugă, as well to Esther Keller and Pravin Ganesanandamoorthy for helpful tips in the lab. We also thank dr. Liliana Török for proving us some samples. Special thanks goes to dr. Adrian Florea and to dr. Carmen Chifiriuc for the scientific input and text correction. Authors also acknowledge the specialists from Genetic Diversity Centre of ETH Zürich for their helpful discussions and advices. The authors are grateful to the reviewers and Journal Editorial board.

\section{Conflicts of Interest}

The authors declare no conflict of interest.

\section{References}

1. Whitton, B.A.; Potts, M. The ecology of cyanobacteria: their diversity in time and space; Springer Science \& Business Media: 2007, https://doi.org/10.1007/0-306-46855-7.

2. Moore, L.R.; Huang, T.; Ostrowski, M.; Mazard, S.; Kumar, S.S.; Gamage, H.K.A.H.; Brown, M.V.; Messer, L.F.; Seymour, J.R.; Paulsen, I.T. Unicellular Cyanobacteria Are Important Components of Phytoplankton Communities in Australia's Northern Oceanic Ecoregions. Frontiers in Microbiology 2019, 9, https://doi.org/10.3389/fmicb.2018.03356.

3. Paerl, H.W.; Huisman, J. Blooms like it hot. Science 2008, 320, 57-58, http://dx.doi.org/10.1126/science.1155398.

4. Török, L. Seasonal succesion of phytoplankton from lakes of the Danube Delta. Acta Oecologica 2005, XII, $15-23$. 
5. Yilmaz, M.; Phlips, E.J.; Tillett, D. Improved methods for the isolation of cyanobacterial dna from environmental samples. Journal of phycology 2009, 45, 517-521, https://doi.org/10.1111/j.15298817.2009.00651.x.

6. Martins, J.; Peixe, L.; Vasconcelos, V.M. Unraveling cyanobacteria ecology in wastewater treatment plants (WWTP). Microbial ecology 2011, 62, 241-256, https://doi.org/10.1007/s00248-011-9806-y.

7. Moreira, C.; Vasconcelos, V.; Antunes, A. Phylogeny and biogeography of cyanobacteria and their produced toxins. Marine drugs 2013, 11, 4350-4369, https://doi.org/10.3390/md11114350.

8. Albrecht, M.; Pröschold, T.; Schumann, R. Identification of Cyanobacteria in a Eutrophic Coastal Lagoon on the Southern Baltic Coast. Frontiers in Microbiology 2017, 8, https://doi.org/10.3389/fmicb.2017.00923.

9. Morin, N.; Vallaeys, T.; Hendrickx, L.; Natalie, L.; Wilmotte, A. An efficient DNA isolation protocol for filamentous cyanobacteria of the genus Arthrospira. Journal of Microbiological Methods 2010, 80, 148-154, https://doi.org/10.1016/j.mimet.2009.11.012.

10. Mirmomeni, M.; Sajjadi Majd, S.; Sisakhtnezhad, S.; Doranegard, F. Comparison of the three methods for DNA extraction from paraffin-embedded tissues. Journal of Biological Sciences 2010, 10, 261-266, http://dx.doi.org/10.3923/jbs.2010.261.266.

11. Abdel-Latif, A.; Osman, G. Comparison of three genomic DNA extraction methods to obtain high DNA quality from maize. Plant Methods 2017, 13, 1, https://doi.org/10.1186/s13007-016-0152-4.

12. Drábková, L.; Kirschner, J.; Vlĉek, Ĉ. Comparison of seven DNA extraction and amplification protocols in historical herbarium specimens of Juncaceae. Plant Molecular Biology Reporter 2002, 20, 161-175, https://doi.org/10.1007/BF02799431.

13. Chandraa, S.; Varshneya, A.K.; Sinhaa, S.; Mathurb, N. A Rapid and Efficient DNA Extraction Method for PCR Based Assays in Activated Sludge. Jour Pl Sci Res 2010, 26, 213-218.

14. Verbylaite, R.; Beisys, P.; Rimas, V.; Kuusiene, S. Comparison of ten DNA extraction protocols from wood of European Aspen (Populus tremula L.). Baltic Forestry 2010, 16, 30.

15. Akkak, A.; Boccacci, P.; Botta, R. An efficient dna-extraction protocol for nut seeds. Journal of food quality 2008, 31, 549-557, https://doi.org/10.1111/j.1745-4557.2008.00219.x.

16. Nair, H.P.; Vincent, H.; Bhat, S.G. Evaluation of five in situ lysis protocols for PCR amenable metagenomic DNA from mangrove soils. Biotechnol Rep (Amst) 2014, 4, 134-138, https://doi.org/10.1016/j.btre.2014.09.008.

17. Dobhal, S.; Zhang, G.; Rohla, C.; Smith, M.W.; Ma, L.M. A simple, rapid, cost-effective and sensitive method for detection of Salmonella in environmental and pecan samples. J Appl Microbiol 2014, 117, 1181-1190, https://doi.org/10.1111/jam.12583.

18. Billi, D.; Caiola, M.G.; Paolozzi, L.; Ghelardini, P. A method for DNA extraction from the desert cyanobacterium Chroococcidiopsis and its application to identification of ftsZ. Appl. Environ. Microbiol. 1998, 64, 4053-4056, https://doi.org/10.1128/AEM.64.10.4053-4056.1998.

19. Kaczyńska, A.; Łoś, M.; Węgrzyn, G. An improved method for efficient isolation and purification of genomic DNA from filamentous cyanobacteria belonging to genera Anabaena, Nodularia and Nostoc. Oceanological and Hydrobiological Studies 2013, 42, 8-13, https://doi.org/10.2478/s13545-013-0058-y.

20. Gaget, V.; Keulen, A.; Lau, M.; Monis, P.; Brookes, J. DNA extraction from benthic Cyanobacteria: comparative assessment and optimization. Journal of applied microbiology 2017, 122, 294-304, https://doi.org/10.1111/jam.13332.

21. Moza, M.I.; Postolache, C.; Benedek, A.M.; Moldoveanu, M.; Spaak, P. Geographical and temporal patterns of cyanobacterial assemblages in the Danube Delta lake complexes. Hydrobiologia 2021, 848, 753-771, https://doi.org/10.1007/s10750-020-04466-w.

22. Tiam, S.K.; Comte, K.; Dalle, C.; Duval, C.; Pancrace, C.; Gugger, M.; Marie, B.; Yéprémian, C.; Bernard, C. Development of a new extraction method based on high-intensity ultra-sonication to study RNA regulation of the filamentous cyanobacteria Planktothrix. PloS one 2019, 14, https://doi.org/10.1371/journal.pone.0222029.

23. Romanescu, G. Morpho-hydrographical evolution of the Danube Delta; Pim: 2005.

24. Coops, H.; Buijse, L.L.; Buijse, A.D.T.; Constantinescu, A.; Covaliov, S.; Hanganu, J.; Ibelings, B.W.; Menting, G.; Navodaru, I.; Oosterberg, W. Trophic gradients in a large-river Delta: ecological structure determined by connectivity gradients in the Danube Delta (Romania). River Research and Applications 2008, 24, 698-709, https://doi.org/10.1002/rra.1136.

25. Oosterberg, W.; Staras, M.; Bogdan, L.; Buijse, A.; Constantinescu, A.; Coops, H.; Hanganu, J.; Ibelings, B.W.; Menting, G.; Navodaru, I. Ecological gradients in the Danube Delta lakes: present state and man- 
induced changes. Lelystad : Institute for Inland Water Management and Waste Water Treatment RIZA 2000, 170.

26. Irimuș, I.A. The hydrological regime of the Danube River in the deltaic sector. In: Tudorancea C, Tudorancea MM, editors. Danube Delta - Genesis and Biodiversity. Leiden, The Netherlands: Blackhuys Publishers 2006, 53-64.

27. Fontana, S.; Thomas, M.K.; Moldoveanu, M.; Spaak, P.; Pomati, F. Individual-level trait diversity predicts phytoplankton community properties better than species richness or evenness. The ISME Journal 2018, 12, 356-366, https://doi.org/10.1038/ismej.2017.160.

28. Enache, I.; Florescu, L.I.; Moldoveanu, M.; Moza, M.I.; Parpală, L.; Sandu, C.; Turko, P.; Rîşnoveanu, G.; Spaak, P. Diversity and distribution of Daphnia across space and time in Danube Delta lakes explained by food quality and abundance. Hydrobiologia 2019, 842, 39-54, https://doi.org/10.1007/s10750-019-04025-y.

29. Tillett, D.; Neilan, B.A. Xanthogenate nucleic acid isolation from cultured and environmental cyanobacteria. Journal of Phycology 2000, 36, 251-258, https://doi.org/10.1046/j.1529-8817.2000.99079.x.

30. Neilan, B.A.; Jacobs, D.; Blackall, L.L.; Hawkins, P.R.; Cox, P.T.; Goodman, A.E. rRNA sequences and evolutionary relationships among toxic and nontoxic cyanobacteria of the genus Microcystis. International Journal of Systematic and Evolutionary Microbiology 1997, 47, 693-697, https://doi.org/10.1099/0020771347-3-693

31. Saker, M.; Fastner, J.; Dittmann, E.; Christiansen, G.; Vasconcelos, V. Variation between strains of the cyanobacterium Microcystis aeruginosa isolated from a Portuguese river. Journal of Applied Microbiology 2005, 99, 749-757, https://doi.org/10.1111/j.1365-2672.2005.02687.x.

32. Jungblut, A.D.; Hawes, I.; Mountfort, D.; Hitzfeld, B.; Dietrich, D.R.; Burns, B.P.; Neilan, B.A. Diversity within cyanobacterial mat communities in variable salinity meltwater ponds of McMurdo Ice Shelf, Antarctica. Environmental microbiology 2005, 7, 519-529, https://doi.org/10.1111/j.14622920.2005.00717.x.

33. Hallmaier-Wacker, L.K.; Lueert, S.; Roos, C.; Knauf, S. The impact of storage buffer, DNA extraction method, and polymerase on microbial analysis. Scientific Reports 2018, 8, 6292, https://doi.org/10.1038/s41598-018-24573-y.

34. Jiang, J.; Alderisio, K.A.; Singh, A.; Xiao, L. Development of procedures for direct extraction of Cryptosporidium DNA from water concentrates and for relief of PCR inhibitors. Appl Environ Microbiol 2005, 71, 1135-1141, https://doi.org/10.1128/AEM.71.3.1135-1141.2005.

35. Schrader, C.; Schielke, A.; Ellerbroek, L.; Johne, R. PCR inhibitors-occurrence, properties and removal. Journal of applied microbiology 2012, 113, 1014-1026, https://doi.org/10.1111/j.1365-2672.2012.05384.X.

36. Palomo, F.S.; Rivero, M.G.C.; Quiles, M.G.; Pinto, F.P.; Machado, A.M.d.O.; Carlos Campos Pignatari, A. Comparison of DNA Extraction Protocols and Molecular Targets to Diagnose Tuberculous Meningitis. Tuberculosis Research and Treatment 2017, 2017, 5089046, https://doi.org/10.1155/2017/5089046.

37. Sellers, G.S.; Di Muri, C.; Gómez, A.; Hänfling, B. Mu-DNA: a modular universal DNA extraction method adaptable for a wide range of sample types. Metabarcoding and Metagenomics 2018, 2, https://doi.org/10.3897/mbmg.2.24556.

38. Moldoveanu, M.; Zinevici, V.; Parpală, L.; Ionică, D.; Păceșilă, I.; Dumitrache, A.; Sandu, C.; Florescu, L. The role of plankton communities in the functional capacity of the Danube Delta ecosystems - a long term study. Muzeul Olteniei Craiova. Muzeul Olteniei Craiova. Studii şi comunicări - Ştiinţele Naturii 2015, 31, 183-188.

39. Kreader, C.A. Relief of amplification inhibition in PCR with bovine serum albumin or T4 gene 32 protein. Appl. Environ. Microbiol. 1996, 62, 1102-1106, https://doi.org/10.1128/AEM.62.3.1102-1106.1996.

40. Demeke, T.; Jenkins, G.R. Influence of DNA extraction methods, PCR inhibitors and quantification methods on real-time PCR assay of biotechnology-derived traits. Anal Bioanal Chem 2010, 396, 1977-1990, https://doi.org/10.1007/s00216-009-3150-9.

41. Opel, K.L.; Chung, D.; McCord, B.R. A study of PCR inhibition mechanisms using real time PCR. Journal offorensic sciences 2010, 55, 25-33, https://doi.org/10.1111/j.1556-4029.2009.01245.x.

42. Farell, E.M.; Alexandre, G. Bovine serum albumin further enhances the effects of organic solvents on increased yield of polymerase chain reaction of GC-rich templates. BMC research notes 2012, 5, 257 , https://doi.org/10.1186/1756-0500-5-257.

43. Lupan, I.; Ianc, B.M.; Ochiș, C.; Popescu, O. The evidence of contaminant bacterial DNA in several commercial Taq polymerases. Biotechnol Lett 2013, 18, 8007-8012. 
44. Scipioni, A.; Bourgot, I.; Mauroy, A.; Ziant, D.; Saegerman, C.; Daube, G.; Thiry, E. Detection and quantification of human and bovine noroviruses by a TaqMan RT-PCR assay with a control for inhibition. Mol Cell Probes 2008, 22, 215-222, https://doi.org/10.1016/j.mcp.2008.02.003.

45. Abbaszadegan, M.; Stewart, P.; LeChevallier, M. A strategy for detection of viruses in groundwater by PCR. Applied and environmental microbiology 1999, 65, 444-449, https://doi.org/10.1128/AEM.65.2.444449.1999. 


\section{Supplementary material}

Table S1. Examples for the molar concentration calculation with different methods.

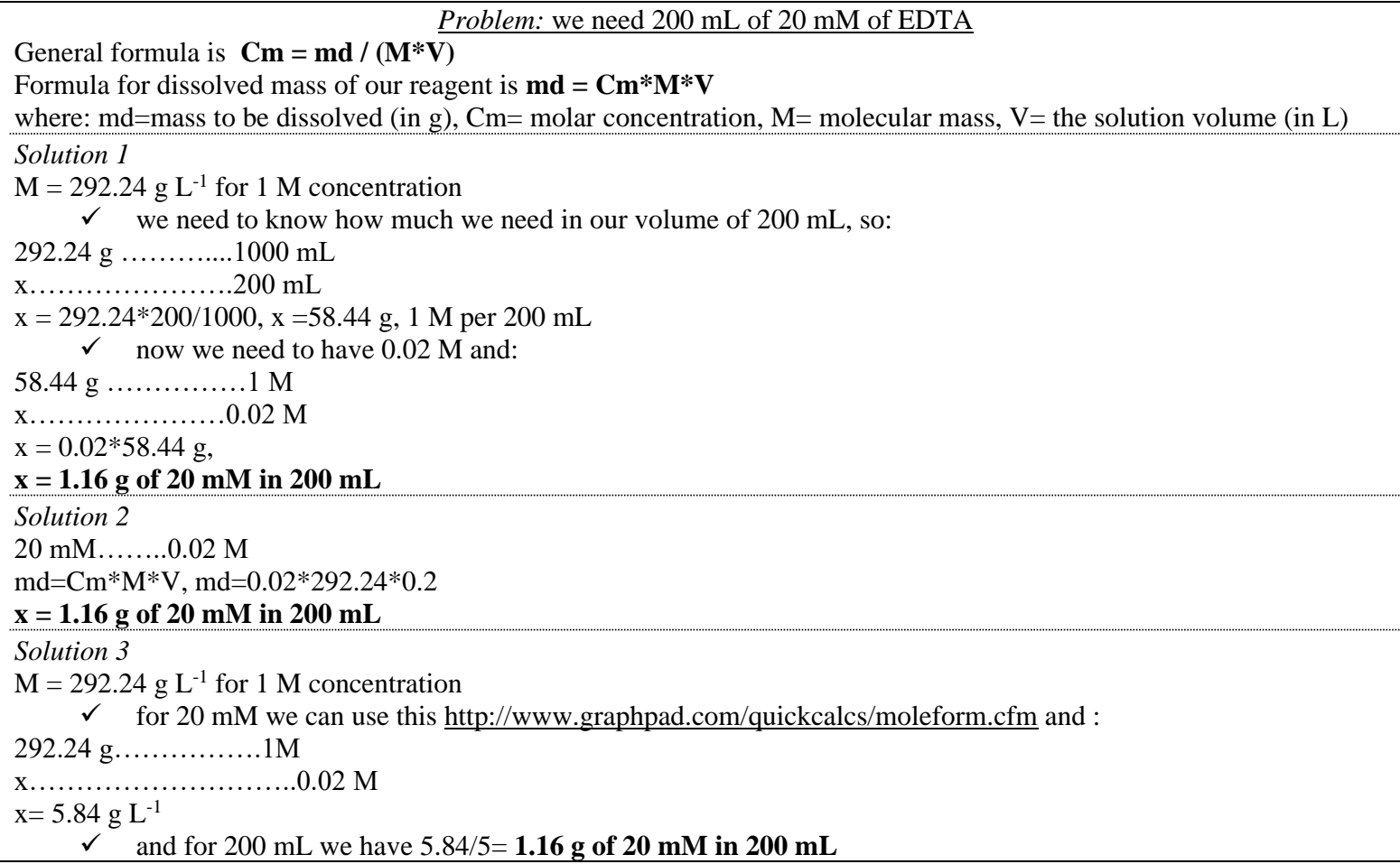

Table S2. Isolated DNA OD for phytoplankton net samples extracted with XS buffer from Danube Delta shallow lakes in March 2015.

\begin{tabular}{c|c|c|c} 
Lake name & DNA conc. & $\mathbf{2 6 0 / 2 8 0}$ & $\mathbf{2 6 0 / 2 3 0}$ \\
\hline Furtuna & 470.7 & 1.62 & 1.16 \\
\hline Băclăneștii Mari & 488 & 1.69 & 1.18 \\
\hline Cuibul cu Lebede & 298.9 & 1.74 & 1.85 \\
\hline Isac & 183.6 & 1.81 & 2.08 \\
\hline Uzlina & 214.8 & 1.67 & 1.81 \\
\hline Gorgostel & 241.9 & 1.72 & 2.01 \\
\hline Merhei & 341.5 & 1.63 & 1.02 \\
\hline Matița & 190.2 & 1.63 & 1.17 \\
\hline Trei Iezere & 793.4 & 1.55 & 1.07 \\
\hline Dracului & 199.4 & 1.62 & 1.17 \\
\hline Roșuleț & 458.6 & 1.53 & 1.08 \\
\hline Roșu & 329.7 & 1.53 & 0.96 \\
\hline Erenciuc & 415 & 1.65 & 1.33 \\
\hline Puiu & 223.6 & 1.7 & 1.9
\end{tabular}

*DNA concentration is given in $\mathrm{ng} \mu \mathrm{L}^{-1}$. 